\title{
Risikobaseret regulering som tillidsbevarende mekanisme i en uforudsigelig verden - rationaler, dilemmaer og paradokser
}

\author{
Af Per Henriksen *)
}

\section{Resumé}

Den moderne verden er kompleks og dynamisk. Usikkerhed og uforudsigelighed råder, og det stiller store krav til den måde, vi forvalter de samfundsmæssige processer på. For i en usikker verden er tilliden til samfundets centrale institutioner og de systemiske organisationer af endnu større betydning, når vi skal opretholde et velfungerende velfærdssamfund. Alligevel oplever vi en række sager, f.eks. relateret til SKAT, sundhedssektoren og den finansielle sektor, der udfordrer vores indlejrede oplevelse af tillid til systemet. Men hvorfor får vi disse sager, og kan de undgås? En del af svaret ligger muligvis i det paradoks, at vi konsekvent søger at håndtere usikkerhed og uforudsigelighed ud fra strategier og principper, der er rodfæstet i en verdensopfattelse af forudsigelige kausale sammenhænge. Artiklen argumenterer for, at den opfattelse har konsekvenser, fordi årsags-virknings-sammenhænge ofte kendetegnes ved det stik modsatte, nemlig uigennemskuelighed og deraf, uforudsigelighed. Artiklen tager afsæt i paradigmet om risikobaseret regulering og kontrol som eksponent for samfundsmæssige strømninger om rationel kausalitet, der har gjort risikostyring til et dominerende, men også tvetydigt svar på næsten alting. På den baggrund diskuteres 3 centrale udfordringer (strategisk ideologi, motiv- / praktik-kobling og risiko- / usikkerheds-tolkning), som risikobaseret regulering bør adressere for at afstemme intention med modernitetens natur. Den overordnede konklusion er, at ureflekteret tiltro til risikobaseret regulering og kontrol som universel metodik, er en farefyldt vej for samfundskontrakten, fordi paradigmet i praksis ignorerer verdens diskontinuitet og betydningen af samme.

\section{Emneord}

Tillid, samfundskontrakt, risiko, usikkerhed, samfundslederskab, paradokser, risikobaseret regulering, kompleksitet.

*) Per Henriksen er ph.d. og tilknyttet Institut for Produktion og Erhvervsøkonomi, Copenhagen Business School. Han arbejder til daglig i DI med luftfartspolitik og som sekretariatschef for brancheforeningen Dansk Luftfart, og har før det mange års ledelseserfaring fra bl.a. mejeriindustrien og luftfartserhvervet. 


\section{A. Introduktion}

\section{Baggrund}

Vores tillid til de samfundsbærende institutioner og systemer er en central mekanisme for at livet i et moderne velfærdssamfund fungerer nogenlunde smertefrit. Men meget tyder på, at tilliden er under pres i disse år. Den opfattelse indgår også i det såkaldte politiske forståelsespapir mellem Socialdemokratiet, Radikale Venstre, Socialistisk Folkeparti og Enhedslisten, der danner grundlaget for den socialdemokratiske regering, der blev dannet i sommeren 2019 (Socialdemokratiet, 2019). Det hedder heri, at "Danmark er et af de samfund i verden, der bygger allermest på tillid. Det er udviklet over generationer, er dybt folkeligt forankret og præger alle dele af vores samfund Desværre er der særligt i de senere år slået skår af tilliden. Det underminerer den samfundskontrakt, vi har med hinanden, og det er alvorligt." (p. 17). I "forståelsespapiret" trækkes referencer til finanskrisen, SKAT's funktionelle kollaps, udbytteskat-sageni, hvidvaskesagerne og Britta Nielsensagen, der sammen med en række andre hændelser er noget, der udfordrer systemernes troværdighed og derigennem vores tillid de lovgivende og udførende magter. At den bekymring over tendenserne i den samfundsmæssige udvikling, der indgår i fundamentet for den seneste regeringsdannelse, ikke er ren lommefilosofi, fremgår blandt andet af OECD's seneste landeundersøgelse (Murtini et al., 2018), hvoraf det blandt andet fremgår, at borgernes oplevelse af institutionernes præstationer er direkte forbundet til tilliden til regering og myndigheder, og senest i Danmark i en undersøgelse, der blandt andet viser, at danskerne er mindre tillidsfulde end tidligere (Frederiksen, 2019) ii. Hvis man har brug for et eksempel på, hvor galt det i yderste konsekvens kan gå, når troværdighed og tillid er eroderet helt bort, kan man i disse år bare rette blikket på Venezuela, hvor det er alles kamp mod alle. Der er vi heldigvis langt fra, men der synes at være indikationer nok til, at vi stopper lidt op og reflekterer mere indgående over de samfundsmæssige tendenser, der kan spores.

Selv om vi heldigvis fortsat kan kalde os borgere i et velfungerende samfund, skal der konstant føres tilsyn og kontrol med, at vores tillid til samfundssystemerne er berettiget. For samfundskontrakten skal opretholdes. Men effektiv kontrol og tilsyn med institutionernes, organisationers og virksomheders arbejde er ikke nogen enkel sag. Det stiller ekstremt store krav til detailviden og faglig indsigt fra kontrolmyndighedens side i den moderne kontekst, hvor teknologier, processer og adfærd udvikler sig med stor hastighed og med mere og mere komplekst indhold. Vi står dermed over for krav, der er vanskelige at opfylde bare med et minimum af ressource-effektivitet, hvis det skal udføres med klassiske kontrol- og tilsynsprincipper. Dertil kommer, at der i moderniteten er tilkommet andre og endnu mere udfordrende dimensioner, herunder ikke mindst de mange forsøg på bevidst og intenderet at undergrave den tillid, vi har fået indlejret gennem generationer. Det er en sammenkobling, der indeholder enorme udfordringer for 
lovgivere og regulatorer at løse på en effektiv og proportional måde, for boniteten af processerne har betydning for os alle. Det er et ægte dilemma.

Derfor har lovgiverne og regulatorerne som en central respons på dilemmaet udformet en anden strategi og nærmest umærkeligt foretaget et paradigmeskifte over den seneste årtier fra den klassiske direkte og detailorienterede kontrolindsats (det man kan kalde "command and controlparadigmet") til det, vi i dag kender som det risikobaserede eller tillidsbaserede reguleringsregime. Kort fortalt betyder det på den ene side, at lovgivningsobjekter på visse områder udvælges efter den risiko, der vurderes at udgøre for samfundet og borgerne, og på den anden side, at kontrol- og tilsynsindsatser målrettes de kontrol- og tilsynsobjekter, hvor risikoen for afvigelser vurderes størst. Hvad angår sidstnævnte er Finanstilsynet, SKAT, Sundhedsstyrelsen/Styrelsen for Patientsikkerhed, Fiskerikontrollen og Trafikstyrelsen alle eksempler på institutioner, der i deres kontrol og tilsyn officielt og formelt bekender sig til det risikobaserede paradigme.

Men det kan synes som et paradoks, at vi i de selvsamme kontekster også finder de eksempler på "skandaler", der er oplistet ovenfor. Det giver anledning til at stille spørgsmålstegn ved, om paradigmet nu er helt ufejlbarligt. Hvis det ikke er tilfældet, er det naturligvis problematisk, at vi i så høj grad bygger en god del af vores tillidsbevarende samfundsprocesser på et paradigme, der måske ikke bidrager til at løse opgaven. Moderniteten er en kontekst af enorm kompleksitet og dynamik, og hvis der ikke er en relevant kobling mellem kontekst og forvaltningsstrategi, risikerer vi, at den forventede effekt bliver en illusion og et selvbedrag, som hvis det ikke udfordres, vil lede til endnu flere skandaler af samme slags. Hvis vi fortsætter upåagtet, risikerer vi at forstærke en ond cirkel, hvor tilliden til de etablerede samfundsstrukturer eroderer med stadig stigende kraft. Hvad det kan føre til, er selvfølgelig uvist. Men en oplagt trussel er stigende erosion af velfærdssamfundets grundlæggende kontrakt om solidaritet, og deraf følgende samfundsmæssig polarisering og ustabilitet. Det er formentlig et uønsket scenario for de fleste af os. Der er derfor god grund til at forholde sig kritisk til logik og rationaler i de etablerede systemer og strukturer.

\section{Formål og problemfelt}

Artiklen tager derfor afsæt i det risikobaserede regulerings- og kontrolparadigme, der har rod i New Public Management og ideologierne om afbureaukratisering og selvregulering. Paradigmet kan ses som en central, men relativt upåagtet eksponent for modernitetens forvaltningsstrategier, der implicit er pålagt den vitale mission at bidrage til opretholdelse af tilliden til de samfundsbærende institutioner. Men som nævnt foran, er samme tillid under pres, blandt andet under påvirkning af en række problematiske sager, der har tæt kobling til forvaltningsmæssige forhold. Det stiller spørgsmålstegn ved boniteten af de forvaltningsmæssige paradigmer, vi sætter vores lid til. Det spørgsmål søges udforsket ved at sammenholde og kontrastere det risikobaserede regulerings- og 
kontrolparadigmes indhold, centrale grundforudsætninger og rationaler med den kontekst, paradigmet er tiltænkt at operere i. Intentionen er herigennem at afdække dilemmaer og eventuelle centrale modsætningsforhold / paradokser, hvis erkendelse kan være afgørende for boniteten af fremtidige forvaltningsstrategier. Det har betydning for disses mulige bidrag til at fastholde og styrke samfundets sammenhængskraft og tilliden til de normer, der er samfundets og fællesskabets grundpiller.

\section{Oversigt over artiklen}

Artiklen er struktureret som følger: først ser jeg lidt nærmere på koblingen mellem tillid og risiko, fordi det er en central del af logikken bag det risikobaserede regulerings- og kontrolparadigme. På den baggrund udvikler jeg 3 teoretiske grundudfordringer, der forudsættes at have betydning for paradigmets reelle bonitet. Derpå diskuterer jeg med nedslag i den for emnet relevante litteratur og udvalgte eksempler disse 3 udfordringers kobling til tillidsdagsordenen og modernitetens natur. På det grundlag identificeres en række indbyggede dilemmaer og paradokser, der har betydning for paradigmets anvendelighed. Konsekvensen af disse dilemmaer og paradokser diskuteres, og afslutningsvis reflekteres over mulighederne for alternative strategier.

\section{B. Tillid og koblingen til risiko}

Tillid har mange former og niveauer. Vi taler f.eks. om interpersonel tillid, når vi f.eks. tager for givet at naboen som aftalt holder øje med huset og får tømt postkassen, når vi er taget på ferie. Eller om tillid til Folketinget, regeringen, om tillid til medierne og objektiv nyhedsdækning, om tillid til politi og domstole, om tillid til de samfundsbærende institutioner, og regner med, at de handler til vores bedste. Grundlæggende er der tale om tillid til de institutioner, der udgør magtens tredeling. Men man kan også trække en tråd til det, der ofte kaldes den fjerde statsmagt, altså mediernes og nyhedsdækningens rolle. Man kan - i hvert fald for dette papirs tema - måske også tillægge en femte "magtfaktor", der ofte er tæt knyttet til presse og nyhedsdækning, nemlig det vi som regel benævner "eksperter", når beslutninger, viden og / eller synspunkter skal formidles og indtages $\mathrm{i}$ vores beslutningsgrundlag.

Disse aktørers troværdighed er forudsætningen for at etablere, opbygge og fastholde tillid (Hardin, 2002), for hvis aktørernes adfærd ikke er i overensstemmelse med det officielle rationale og motiv i en given sag eller politikområde, eroderes troværdigheden, og det har negativ effekt på den tillid, der er etableret. Man kan hertil tilføje, at udkommet af centrale politikker ligeledes har betydning for tillidsfastholdelsen. Så det er helt centralt for samfundsordenen, at vi har tiltro til de samfundsbærende institutioner og tiltro til, at de aktører, der bør fortjene vores tillid, handler moralsk og etisk forsvarligt - både i forhold til egne aktiviteter og embedsførelse, men så sandelig 
også til at sikre, at vores medborgere følger regler og normer. Og hvis de ikke gør, at der så indtræder relevante og proportionale konsekvenser. Men det indeholder også dilemmaer i forhold til det klassiske "command and control"-paradigme, for som Anthony Giddens har påpeget, kendetegnes moderniteten også ved, at komplekse samfundsstrukturer "udlejres" i form af ekspertsystemer, netop fordi kompleksiteten er enorm (Giddens, 1990). Netop "udlejring" ser Giddens som et centralt træk ved moderniteten, og det har betydning for tillidsperspektivet. Der er, som Giddens anfører, en grundlæggende kobling mellem mekanismerne for tillid og modernitetens udlejring til ekspertsystemer (Ibid.). Som vi skal se senere, har netop dette fænomen betydning i relation til et "ekspertsystem" som det risikobaserede reguleringsparadigme. Man kan således sige, at udlejring i sig selv på den ene side indeholder et dilemma for beslutningstagerne i afbalanceringen mellem kontrolafgivelse, ressourcer og kompetencer, men dertil også et paradoks, netop fordi udlejringen i sig selv bidrager til at øge den kompleksitet, som den er tiltænkt at reducere eller løse.

Det er netop i overstående relationer, at spørgsmålet om det rette valg af reguleringsregime og kontrol- og tilsyns-strategier dukker op. Dertil kommer et underliggende spørgsmål om, hvorfor det risikobaserede reguleringsregime er blevet et dominerende paradigme, og hvilke effekter og konsekvenser, det har ført med sig. Men først må vi se lidt nærmere på, hvordan koblingen mellem tillid og risiko kommer ind i billedet.

Det enkle svar er, at tillid som fænomen og mekanisme er noget, der rækker ud i fremtiden, og dermed ud i det ukendte og uforudsigelige. På den måde er det en slags rationaliserende mekanisme, der substituerer for den vished og viden, som man i nuet ikke besidder. For hvis vi har fuld vished og viden, er der ingen usikkerhed, og dermed heller ikke nogen potentiel risiko. Vi kender udfaldet og har ikke behov for at etablere en tillidsrelation. På den måde hænger tillid også sammen med usikkerhed og deraf også risiko. Niclas Luhmann (Luhmann, 1999) har udtrykt tillid som en mekanisme til reduktion af social kompleksitet. Luhmann anfører også (Ibid.), at der i det moderne højkomplekse samfund er øget behov for tillid - på det personlige plan såvel som til "systemerne". Luhmann skelner her mellem personlig tillid og systemtillid. Og netop begrebet "systemtillid" vil være vigtig for forståelsen af de drivende kræfter for et moderne kontrolorienteret paradigme, der bygger på risikostyring. Hvor den personlige tillid ses som baseret på, hvorvidt den personificerede "modpart", hvis handlinger man er afhængig af, fremstår som værende tillidsværdig, opfattes systemtillid som vores tillid til de sociale systemer, f.eks. til kontinuiteten ved pengesystemet eller det politiske system. Når systemtilliden er etableret, er den ifølge Luhmann mere modstandsdygtig overfor "anslag" og svigt end den personlige tillid, fordi "de kan hele tiden forklares specielt eller blive afreageret, mens den personlige tillid kan bringes til afslutning p.g.a. småforræderier. Systemtilliden behøver ikke hele tiden at blive lært på ny" (Luhmann, 1999:107). Man kan således sige, at der med modernitetens øgede kompleksitet og dynamik er skabt et øget behov for at 
fastholde systemtillid, som vi søger at afdække gennem nye kontrolmekanismer, herunder med implementering af risikobaserede ekspertsystemer og instrumenter. Når eksempelvis kredit-ratingfirmaer som Standard \& Poors og Moody's inddrager audits af virksomheders risikostyringsapparat i deres ratings, kan det jo netop ses som et forsøg på at bidrage til tillidsopbygningen, et blåt stempel for, at "I kan trygt investere her". Dermed anvendes risikostyringsapparatet som en slags "udlejret" kontrolapparat, der skal medvirke til at etablere og fastholde tillid til "systemet" for den eksterne anskuer, trods den umiddelbare uigennemskuelighed og kompleksitet.

Men der er forskelle i, hvordan relationerne specifikt opfattes. I kontrast til Luhmann, der som nævnt anskuer tillid som usikkerhedsreducerende, ser såvel Ulrich Beck (Beck, 1992) som Frederiksen (Frederiksen, 2014), tillid som en mekanisme til at relatere til usikkerhed. (Uslaner, 2013) anfører dertil, at tillid reducerer individers risiko-perceptioner uafhængigt af personlige erfaringer. Tillid forudsætter risiko, og er dermed et alternativ til risiko. Anthony Giddens definerer tillid som tiltro til pålideligheden hos en person eller systemer hvad angår udkommet af givne handlinger, og ser også tillid og risiko som forbundne fænomener, hvor tillid bidrager til at reducere farerne ved givne handlinger (Giddens, 1990).

Men upåagtet disse opfattelsesforskelle og nuancer i tillids-risiko-perspektiverne, er der en etableret og anerkendt kobling mellem tillid, usikkerhed og risiko, og det er rigeligt for denne artikels sigte. Her er det mest centrale, hvordan vi relaterer usikkerhed og risiko til hinanden, og hvordan den relation spiller ind i forhold til det risikobaserede reguleringsregime, fordi vi her taler vi om tilliden til de centrale samfundsinstitutioner og systemiske organisationer. Altså det der med Luhmanns ord benævnes systemtillid. Med ovenstående kan man således sige, at der kan være en logisk og rationel kobling mellem tillidsperspektivet og det risikobaserede reguleringsparadigme. Men denne logiske kobling besvarer ikke spørgsmålet om, hvor vidt det risikobaserede reguleringsparadigme kan tjene sit eksplicitte formål på effektiv vis i alle sammenhænge. For at komme nærmere på et svar på dette spørgsmål opstiller jeg tre grundudfordringer, som paradigmet i sin anvendelsesmæssige udstrækning i hvert fald (mindst) bør kunne give rimeligt klare svar på.

For det første, og som jeg argumenterer nærmere for senere, kan paradigmets anvendelse og effektivitet bero på en forudsætning om en stabil og relativt uforanderlig kobling mellem mål, strategi og praktik. Med andre ord bliver spørgsmålet, om der foreligger en forudsætning om strategisk forudsigelighed, dvs. om paradigmet skal opfattes som det Ralph Stacey har kaldt "Tools and Techniques of Instrumental Rationality" (Stacey, 2012), der bygger på en underforstået forudsætning om effektiv kausalitet mellem mål, strategi og udkomme. 
Et andet forhold knytter sig til tilstedeværelse eller fravær af sammenhæng mellem den formelle politiske drivkraft for at iværksætte anvendelsen af det risikobaserede reguleringsparadigme og dets praktiske udfoldelse. Hvis en sådan sammenhæng i praksis er modsætningsfyldt eller ligefrem paradoksal af natur, vil der bestå en risiko for, at udkommet af paradigmets anvendelse bliver et andet end det forventede.

For det tredje vil paradigmets anvendelsesmæssige udstrækning afhænge af, om det i tankesæt, ideologi og praktik kan opfange og håndtere "modernitetens diskontinuitet" (Giddens, 1990). Michael Power bruger termen "interconnectivity" (Power, 2009), der kendetegner den moderne verdens høje kompleksitet og dynamik, hvori det er vanskeligt at identificere kausale koblinger. Med det mener jeg, at hvis paradigmets ideologi og praktik viser sig at være fokuseret og indrettet på at håndtere lineære koblinger mellem årsag og virkning, sådan som det er iboende den klassiske risikostyrings metode, må man formode, at dets anvendelsesområde begrænses til et sådant domæne, der i sin natur vil tilbyde en mulighed for at identificere relativt objektive kausale koblinger. Hvis paradigmet skal kunne opfange og håndtere verdens diskontinuitet, vil det også have betydning, hvordan vi relaterer usikkerhed og risiko til hinanden. Det betyder i praksis, at vores risiko- og usikkerhedsopfattelser, og deraf følgende tolkninger, også vil have betydning for det risikobaserede kontrolparadigmes anvendelsesområde og effektivitet.

Min påstand er, at de 3 grundudfordringer, altså 1) udfordringen om strategisk forudsigelighed, 2) udfordringen om kobling mellem formel og reel drivkraft, og 3) udfordringen om usikkerhedens kontrollerbarhed, vil have kritisk betydning for anvendelse og effektivitet af det risikobaserede reguleringsparadigme, og dermed kan bidrage til at forklare, hvorfor det som forvaltningsstrategi ikke altid synes at levere det forventede udkomme. Det analyseres og diskuteres nærmere i det følgende afsnit.

\section{Det risikobaserede regulerings- og kontrolparadigme og dets grundudfordringer}

Koblingen mellem tillid, usikkerhed og risiko etablerer - i hvert fald teoretisk - et logisk rationale for risikobaseret regulering som en potentielt tillidsbevarende mekanisme. Hvor vidt den ideologi kan opfange dynamikker og kompleksiteter og en verden fyldt med "intention" for at bryde igennem bolværkerne, eller om det blot er en ideologi, der er båret af tiltroen til instrumentel rationalitet (Stacey, 2012) mellem værktøj og kausalt udkomme, er en anden sag. Men før diskussionen om de 3 grundudfordringer, vil vi se lidt nærmere på paradigmets indhold, sådan som det anskues af dets fortalere. 


\section{Paradigmet - hvad handler det om?}

Det risikobaserede regulerings- og kontrolparadigme (RBRK i det følgende) har over de seneste 20 25 år i stigende omfang, men formentlig umærkeligt for mange, penetreret samfundslivet. Det er blevet en udbredt regulerings- og forvaltningsstrategi i mange sektorer, heriblandt i miljøpolitikken, i finanssektoren, i fødevaresektoren, i transportsektoren, i sundhedssektoren og hvad der er helt aktuelt med danske øjne, også i skattemyndighedernes kontrol- og tilsynsstrategi (Black \& Baldwin, 2012), (Lloyd-Bostock \& Hutter, 2008), (C Hood, Rothstein, \& Baldwin, 2001). Meget tyder på, at den diskurs, der siden slutningen af 1990'erne har gjort risikostyring til et allestedsnærværende fænomen i virksomhedernes styrings- og ledelsesstrategier, ikke mindst udtrykt gennem virksomhedernes adoption af styringsmæssige teknologier som Enterprise Risk Management, og formaliseret i internationale rammeværker som COSO (COSO, 2004, 2016) og ISO (ISO, 2009), også er blevet adopteret i lovgivernes forvaltningsstrategier (Henriksen, 2018a). OECD har sammen med IRGC (International Risk Governance Council) længe været centrale advokater for tankesættet (se blandt andet (OECD, 2010) og (Allio et al., 2015), der derigennem blandt andet har påvirket mange dele af EU-lovgivningen, herunder i reguleringen af EU's finanssektor (EBA), miljø (EEA), luftfartssikkerhed (EASA) og jernbanesikkerhed (ERA).

Lad os gå lidt nærmere på paradigmets indhold. RBRK-paradigmet kan ses som en politisk styringsideologi, der indeholder forskellige styringsobjekter og forvaltningsniveauer. (Black, 2010) har peget på, at RBRK kan anskues ud fra tre perspektiver. På makro-niveau er der tale om reguleringen af risici for samfundet i bred forstand, dvs. sundhed, sikkerhed, miljø og økonomien. Her bruges den risikobaserede tilgang af lovgiverne til at afgøre, hvilke områder der skal prioriteres og reguleres, og i givet fald niveauet af forebyggende foranstaltninger. Et helt aktuelt eksempel i denne sammenhæng vil f.eks. være risikovurderinger og deraf følgende politisk-strategiske beslutninger om pandemi-strategi og -beredskab.

Det andet element er sektor-specifikt og henviser til reguleringen af banker og forsikringsvirksomheders anvendelse af interne risikostyrings-modeller i fastlæggelsen af deres kapitalberedskab. Vi taler her ikke mindst om Basel II-kravene og EU's direktiv om kapitalberedskab. Når finanssektoren fremhæves specifikt, er det selvfølgelig, fordi det er en sektor, der har afgørende betydning for et velfungerende samfundsliv, nationalt som internationalt. Her behøver vi kun at tænke på finanskrisen i 2007/08 for at blive mindet om det.

Det tredje element er langt mere operationelt, og henviser til anvendelsen af systematiske risikostyringsbaserede rammeværker for kontrol og tilsyn med håndteringen af regulatoriske eller institutionelle risici med det formål at tilsikre, at den pågældende myndighed når sine målsætninger (der skal spejle de overordnede mål, der er defineret på makro-niveauet). Fokus er her især rettet 
mod myndighedens beslutningstagen om prioriteringen af kontrolaktivitet og anvendelsen af tilsyns-ressourcer ud fra en undersøgelse (assessment) af de risici, et givent kontrolobjekt påfører myndighedens målsætninger (Black, 2012).

Jeg behandler i det følgende paradigmets 3 niveauer under ét, først og fremmest fordi det ene ikke kan leve uden det andet, men dog med særlig vægt på det tredje element, kontrol- og tilsynsdelen, dels fordi tankesættet her føres ud i livet, og fordi en række indbyggede modsætninger særligt kommer til syne her. Men måske er der også en indbygget forskel mellem niveauerne. På makroniveau synes det umiddelbart meningsfuldt at tænke usikkerhed og risiko ind i forhold til valget af politiske indsatsområder og under hensyn til, hvad der udgør trusler for samfundsordenen og netop systemtilliden. I teorien taler vi her om at søge indsigt i potentielle fremtidige udviklinger, der kan indeholde trusler og farer for opretholdelse af samfundssystemet. Her er det en slags drivkraft for at udvikle beskyttelse mod uønskede påvirkninger af samfundet og borgerne, og netop det der sker, når der fremadrettet udformes strategier og regulering i forhold til terrorisme, databeskyttelse, fødevaresikkerhed, pandemier osv. Den særlige udfordring melder sig nok primært i det udførende forvaltningsniveau, netop fordi aktiviteterne her bliver udfordret af relationen til de tre grundforudsætninger.

\section{Udfordringen om strategisk forudsigelighed}

Hvis man reflekterer nærmere over den 3-deling, som (Black, 2010) har opstillet, jf. ovenfor, er det nærliggende at hævde, at den principielt ikke adskiller fra et klassisk strategi-design, sådan som det i mange tilfælde udmøntes i forretningsorienterede organisationer. Lovgiverne definerer politiske (strategiske) mål, f.eks. et mål for maksimal ventetid i sundhedssektoren ved livtruende sygdomme, et mål om, at der ikke må forekomme ulykker med alvorlig personskade på jernbanen eller et mål om, at finanssektoren skal polstres så tilpas meget, at finanskrisen ikke gentager sig. I større eller mindre detaljeringsgrad vil lovgiver som regel også formulere strategier for at opfylde målsætningerne. I finanssektoren f.eks. udtrykt ved Basel II-kravene, i sundhedssektoren f.eks. ved at tilføre ekstra ressourcer til sygehusene eller ved at indgå politiske aftaler om opgradering af jernbaneinfrastrukturen og vedtage ny lovgivning, der styrker en målrettet ramme for tilsynsmyndighedens tilsyn med jernbanevirksomhedernes sikkerhedsledelse. Så når vi til det taktiske niveau, hvor mål og strategi skal føres ud i livet, altså rammer og konkrete tilsynsstrategier for den pågældende udmøntende myndigheds varetagelse af tilsyns- og kontrolaktiviteterne.

Et helt aktuelt eksempel for denne strategiske tankebane kan vi finde i den nuværende regerings klimapolitik. Med målet om 70 \% CO2-reduktion i 2030 i forhold til 1990, skal strategien forankres i en klimalov, der skal suppleres med konkretiserede sektoraftaler og handlingsplaner. Det skal nogen følge op på, pålægge korrigerende handlinger og eventuelle sanktioner. 
Koblingen mellem mål, strategi og modernitetens diskontinuitet gør det nærliggende at bygge diskussionen på Ralph Staceys (og Chris Mowles') udlægning af strategisk ledelse (Stacey, 2007), (Stacey \& Mowles, 2016), der med baggrund i teorien om komplekse interaktioner (Complex Responsive Processes ${ }^{\mathrm{iii}}$ ), tager afsæt i en opfattelse af verden og organisationer som noget komplekst og uforudsigeligt, og dermed kritisk udfordrer den klassiske rationalistiske tænkning i strategisk ledelse. Jeg tillader mig hermed også at udstrække Staceys ideer om komplekse interaktioner i organisationer til en væsentligt bredere kontekst, hvor vi har at gøre med interaktioner både i og mellem organisationer, der i forhold til den konkrete strategi agerer i et endnu mere komplekst samspil. Grundantagelsen i den klassiske kausal-rationalistiske tænkning, altså den klassiske design-skole i strategisk ledelse, er, at det er muligt at designe globale ("population-wide") udviklingsmønstre ex ante, og at man dermed med rimelig sikkerhed kan forudsige udkommet af en given handling eller strategi, en sikkerhed, der er stor nok til at vælge mellem forskellige strategiske optioner. Det tankesæt forholder Stacey og Mowles sig kritisk til, ud fra den grundlæggende pointe, at klassisk strategisk planlægning ikke er bestemmende for, hvad der sker i en organisation. Pointen er i stedet, at udkommet afhænger af interaktioner af handlinger båret af ønsker og intentioner mellem organisationens enkelte aktører og til aktørerne $\mathrm{i}$ andre organisationer. Karakteren og effekten af sådanne interaktioner kan ikke forudsiges. Det komplekse interaktions-perspektiv understreger således uforudsigeligheden i langsigtede, globale udviklingsmønstre. Dermed kan en plan eller strategisk design for udvikling ifølge Stacey og Mowles kun opnå sit intenderede udkomme i sammenhænge, hvor tidsperspektivet er kort, og kun, hvis der er tale om handlinger, der er repetitive og dermed af natur indeholder et grundlag for sandsynliggørelse og dermed en rimelig grad af forudsigelighed. Dermed taler vi også om sammenhænge, der er identiske med Frank Knights snævre risiko-begreb, som jeg kommer tilbage til nedenfor.

Men perspektivet understreger også et andet centralt forhold, nemlig at ingen enkelt aktør eller mindre gruppe af aktører, f.eks. en organisations ledelse (eller regering), kan styre udkommet af en given strategi, fordi de ikke kan være i kontrol med (eller have viden om) intentioner, interaktioner og samspil mellem organisationens individuelle aktører og grupper af aktører. Der er på samme tid et samspil og indbyrdes påvirkningskræfter i spil mellem lokale interaktioner og globale udviklingsmønstre. Dermed er, siger Stacey og Mowles, emergerende globale udviklingsmønstre paradoksalt forudsigelige og uforudsigelige på samme tid, men specielt fuldstændigt uigennemskuelige i detaljen i det lange tidsperspektiv (Stacey \& Mowles, 2016:365). Strategibegrebet ophører dermed at kunne forstås som realiseringen af et enkelt individs intention eller ønske om organisationens fremtidige tilstand (Stacey \& Mowles, 2016:301). 
Der er nok intet sted, hvor betydningen af de komplekse interaktioner, som Stacey og Mowles peger på, er så udfordrende som i den politiske verdens processer med realiseringen af politiske mål og strategier. Hvis man opstiller så markant ambitiøse politiske mål, der samtidig er omgærdet med så stor opmærksomhed og vigtighed af borgerne som i klimapolitikken, vil det selvsagt have stor betydning for tilliden til det politiske system, hvis det i sidste ende viser sig at være tomme ord og varm luft. Den manglende tilstedeværelse af instrumentel rationalitet, som Stacey og Mowles bringer i spil, stiller store krav til samfundslederskabet, for der er mange ideologier og værdier i spil hos mange forskelligartede aktører. Det gælder blandt politikerne selv, i interesseorganisationerne med hver deres motiver, NGO'er med løsningsorienterede eller militante tilgange, blandt erhvervslivets forskellige sektorers aktører og blandt mange individuelle borgere i og uden for de direkte organisatoriske cirkler. Alle har en holdning til klimapolitikken og vil forsøge at påvirke udviklingen på hver sin vis og ud fra mange forskellige ideologier og motiver, såvel individuelt, i lokale interessegrupper og i større organisatoriske sammenhænge. Samtidig står politiske beslutningstagere i det dilemma, at de skal afveje og prioritere risici og muligheder i forhold til samfundets ressourcer, oplevelse af kritisk betydning og nødvendighed, samt ikke mindst i et krydsfelt af forskellige og ofte modsatrettede interesser. Det krydsfelt vil uvægerligt resultere i beslutninger, der efterfølgende kan vise sig mere eller mindre heldige, netop fordi man handler i usikkerhed. Den virkelighed understreger betydningen af Stacey og Mowles pointe om paradokset mellem forudsigelighed og uforudsigelighed. Mønstre udvikler sig uden plan ind i det ukendte såvel lokalt som globalt på samme tid. Chris Mowles udlægger også paradokset fra en anden vinkel: at vi former hvad vi skal arbejde med, samtidig med at det former os (Mowles, 2016:79). Det er en kompleksitet, der fordrer stor bevidsthed blandt beslutningstagerne om disse mekanismers eksistens og betydning.

Den udfordring bliver ikke mindre, når Stacey og Mowles også påpeger, at vi i det statslige domæne er omgivet af så komplekse strukturer og interaktioner i forskellige organisatoriske sammenhænge, at "ledere" (i bred politisk betydning) er nødt til at arbejde med 2-ordens abstraktioner. Man kan ikke være til stede overalt og kan derfor vanskeligt deltage direkte i de organisatoriske interaktioner. Det adskiller sig ikke fra den situation, som ledere befinder sig i, når de opererer i komplekse koncernstrukturer. I modsætning til 1-ordens abstraktioner, der kan anskues som generaliseringer ud fra de erfaringer, der opsamles gennem lokale interaktioner og nærheden til de forskellige aktører, må ledere gøre brug af 2-ordens abstraktioner i de komplekse organisatoriske situationer. Her er man langt væk fra den direkte oplevelse og erfaring, hvorfor man i stedet er nødsaget til at manipulere fra 1-ordens abstraktioner (narrativet, deltagelsen i den direkte konversation og påvirkning) til 2-ordens abstraktioner (i form af præsentationer, notater, modeller, analyser, forecasting, modellering, standardisering, regler og mål mm.). 
I den strukturelle kompleksitet må man altså finde andre måder at udtrykke sig på, dvs. gennem simplificering i form af 2-ordens abstraktioner. Det ser Stacey og Mowles ikke som negativt, men som nødvendigt og de eneste praktisable mekanismer i modernitetens strukturelle kompleksitet. Men i forhold til realiseringen af politiske mål og strategier udgør det et særligt dilemma og et påtrængende opmærksomhedspunkt, fordi det indebærer mange farer og risici. Mål er i sig selv abstraktioner, og brugen af 2-ordens abstraktioner vil uundgåeligt forstærke muligheden for mangeartede tolkninger, for ignorering - eller for at blive opfyldt formelt, men under tabet af den pågældende organisations principielle formål (Christiansen, Kjærgaard, \& Hartmann, 2012). Sådanne udviklinger er i Stacey og Mowles' perspektiv ikke nødvendigvis negative for den forretningsbaserede organisation, fordi det i sig selv kan bringe positiv forandring og udvikling for organisationen. Som (Stacey \& Mowles, 2016:425) også peger på, er netop spændingen mellem det, de benævner som henholdsvis legitime (officielle) temaer og uformelle skygge-temaer i en organisation vigtige, fordi spændingen mellem de to er en potentiel kilde til mangfoldighed, der er kritisk for en organisations evne til at udvikle sig i nye retninger. Men i forhold til de statsligt udpegede risiko-domæner af samfundsmæssig betydning er stor volalitet (usikkerhed) i aktørernes fortolkninger, og de følgende udkommer ikke specielt ønskelige, hvis systemtilliden skal opretholdes, fordi udkommet af centrale politikker har betydning for tillidsfastholdelsen. Det gælder i særdeleshed ikke, hvis udkommet fører i andre retninger end de ønskede. Stacey og Mowles angiver selv et sådant eksempel med ventetidsgarantier i det britiske sundhedssystem (NHS), hvor kravet om nedbringelse af ventetider førte til "kreative" initiativer ved f.eks. at sende patienter hurtigt hjem efter operationer, hvilket førte til stigning i antallet af genindlæggelser (Stacey \& Mowles, 2016:399). Sådanne træk er formentlig heller ikke ukendte i det danske sundhedsvæsen, hvor varigheden af indlæggelser af samme årsag er markant reduceret over tid, og hvor omfanget af genindlæggelser er tilsvarende øget.

Et andet eksempel, der kan knyttes til de organisatoriske interaktioner og de mekanismer som (Christiansen et al., 2012) fandt, ligger i den potentielle konflikt mellem myndighedens iboende eksterne fokus, og de interaktioner, der finder sted internt. At den konflikt kan være kritisk for tillidsdimensionen, har vi for nylig set i et par danske myndighedsorganisationer, der opererer på basis af risikobaseret tilsyn og kontrol. Dels sagen om kvoteadministration på fiskeriområdet, hvor Rigsrevisionen har rettet en skarp kritik af Miljø- og Fødevareministeriets forvaltning af Folketingets intention om, at fiskekvoter ikke må koncentreres på for få hænder. Den skarpe kritik var relateret til, at ministeriet ikke havde udmøntet Folketingets intention ved ikke at fastsætte konkrete mål for, hvad der skulle til, før kvoterne var koncentreret på for få hænder, samt at ministeriet ikke fulgte systematisk op på udviklingen i den samlede kvotekoncentration over tid (Rigsrevisionen, 2016). Man kan således sige, at ministeriets bevidste eller ubevidste tolkning af Folketingets intention førte udviklingen i den diametralt modsatte retning af det politiske mål. 
Trafikstyrelsens nylige sag om erhvervspiloters helbredsattester understreger ligeledes vigtigheden af, at mål og strategi under påvirkninger fra organisatoriske interaktioner langt fra altid fører til det ønskede udkomme. Valide helbredsattester for piloter er selvsagt af vital betydning for vores tillid til, at myndighederne er garant for høj flyvesikkerhed. Derfor vakte det en del bekymring, da det i foråret 2019 viste sig, at styrelsens ansvarlige for tilsynet med de specielt uddannede flyvelæger og klinikker selv havde omgået de meget strikse krav til flyvelæger i sin egen flyvelægeklinik, der opererede under navnet doctors.dk (Transportministeriet, 2016). I denne sag var styrelsens øverste ledelse over en længere periode ofte blevet gjort opmærksom på den forvaltningsmæssige problematik i den manglende arms længde mellem tilsyn og egen forvaltning, men havde upåagtet dette valgt sin egen fortolkning af reglerne.

Ovenstående eksempler er blot et par blandt mange, der illustrerer pointen om, at der langt fra altid er lineær kobling mellem intention og resultat. De fleste af de eksempler, jeg viser i de efterfølgende afsnit, kan også indtænkes i dette perspektiv. Og der er mange flere. De perspektiver, der fremkommer af Stacey og Mowles' tanker om strategi og komplekse interaktioner, gør således ikke verden nemmere at håndtere. Tværtimod står vi tilbage med en række dilemmaer, der ikke findes nemme løsninger på. Men jeg vil vove den påstand, at de fleste, der har arbejdet med strategisk ledelse, erfaringsmæssigt godt ved, at virkeligheden forholder sig sådan. Det er et godt udgangspunkt, men alligevel handler vi som regel modsat.

Nils Brunsson (Brunsson, 2006) har på glimrende vis illustreret dette paradoks, hvori vi søger forandring ud fra en rationel antagelse om lineær kobling mellem strategi og udkomme, men i praksis afviger fra de rationelle principper. Men Brunsson har fokus på, at selve afvigelsen fra det rationelle perspektiv i sig selv leverer grundlaget for at opretholde håbet om rationalitet. Folk ser ingen grund til at forlade det rationelle paradigme, før der foreligger et overbevisende alternativ, heller ikke selv om ens erfaring fortæller noget andet. Resultatet er, siger Brunsson, stabilitet. Stabilitet forstået på den måde, at vi gør de samme ting igen og igen, på samme måde og med samme mål, men uden at tage ved lære af vores erfaringer. Den verden Brunsson påviste med "Mechanisms of Hope" (Brunsson, 2006), er en verden af forudsigelige mønstre, hvor processen i sig selv bliver vigtigere end udkommet. Synliggørelsen af vores iboende tendens til at fastholde det rationelle paradigme, og klarlæggelsen af, hvorfor vi gør det, er netop grunden til, at jeg her fremdrager Brunsson. For det vil være usandsynligt, at organisatoriske (og meta-organisatoriske som de statslige) processer, vil udfolde sig på anden vis, hvis der ikke er bevidsthed om det indbyggede paradoks, dets konsekvenser og muligheden for at tilgå verden på anden vis. 
Derfor er det af betydning, ikke mindst for tillidsperspektivet, at svaghederne ved det rationelle paradigme og faldgruberne ved kritisk og ureflekteret satsen på forvaltningsstrategier, der er rodfæstet i tiltro på instrumentalitet, erkendes af beslutningstagerne. Uden denne erkendelse, kan vi blot vente på mere af det samme. Med modernitetens diskontinuitet in mente, kan vi kun forvente en stadig strøm af skandaler i og omkring de samfundsbærende institutioner, med den uønskede konsekvens, at tilliden til samfundskontraktens soliditet fortsætter med at erodere. Det er det modsatte af intentionen.

I forhold til Brunssons fokus, er Stacey og Mowles primært interesserede i de organisatoriske processer og konsekvenserne af de organisatoriske interaktioner, der har betydning for koblingerne mellem mål, strategi og udkomme. Man kan sige, at der i teorien om komplekse interaktioner reelt set ikke eksisterer et håb om rationalitet og lineære sammenhænge, men i stedet er det en kompleks verden fyldt med uforudsigelighed og paradokser. Men det perspektiv har konsekvenser, der ikke er nemme at håndtere. Hvis vi for en stund vender tilbage til eksemplet om klimapolitikken, tydeliggøres udfordringen. Heri fremtræder netop det iboende paradoks, der ligger i regeringens strategi, nemlig at vi skal redde klimaet, men det må ikke koste noget. Vi skal altså forandre vores levevis og samtidig forblive de samme (Mowles, 2016). Det synes at være et klart paradoks, men som Mowles også anfører, er erkendelsen af et paradoks første skridt i retning af et opgør med det rationelle paradigme (Ibid.). For samfundets beslutningstagere betyder det, at politikken ikke, som det ofte er tilfældet, stopper med selve beslutningen om et givent politisk mål og en overordnet strategi, hvorefter man kan overlade udviklingen til forvaltningsniveauet alene. Selv om de politiske samfundsledere ikke kan være i kontrol over udfaldet, kan de påvirke retning og proces. Det forudsætter bevidsthed om de komplekse interaktioners betydning, og konkret og konstant deltagelse i det sociale liv, der omkranser beslutningens virkeliggørelse. Man kan, som Mowles (2016:238) da også gør, antage 2 yderpoler for ledelse: enten hvor ledere forudsættes og tiltros, at kunne forudse og kontrollere, eller hvor det antages, at der er grænser for denne evne. Hvilken man antager, har konsekvenser.

Sammenfatning og implikationer: Man kan sige, at det statslige risiko-domæne udgør et særligt udfordrende eksempel på betydningen af komplekse interaktioner, fordi forventningen til kausal overensstemmelse mellem mål, strategi og udkomme på samfundskritiske områder er høj og af stor betydning for fastholdelse af systemtillid. I det perspektiv afviger det fra Stacey og Mowles' opfattelse af de positive udkommer af spændingerne i komplekse interaktioner i forretningsorganisationer. Der er ud fra tillidsperspektivet ikke rum for større uoverensstemmelser mellem mål og udkomme. Lovgiverne kan ikke forudsætte strategisk forudsigelighed, men bør agere ud fra den modsatte forventning. Derfor er de politiske beslutningstageres opmærksomhed og ageren på selve de risici, der er iboende i konflikten mellem den klassiske strategiopfattelse og den 
strategiopfattelse, der ligger i teorien om komplekse interaktioner, helt afgørende faktorer for fastholdelsen af systemtillid. Men det er samtidig en udfordring af dimensioner for, som Nils Brunsson har vist, ligger håbet om den rationelle drøm dybt i de fleste af os (Brunsson, 2006), og det gør det tillokkende i sin umiddelbare enkelhed at fastholde en strategiopfattelse, der bygger på rationel kausalitet. Men hvis man anerkender betydningen af Stacey og Mowles' pointer, og samtidig tager tillidsfastholdelsen som mål, vil de politiske beslutningstagere og deres rådgivere være nødsaget til at gå nye veje, der indebærer mere observans på processerne, deres udvikling, i og mellem organisationer, og så gøre alt hvad man ledelsesmæssigt kan, for at holde det på banen. Som Stacey og Mowles også bemærker, så er det ligegyldigt, hvor magtfuld du er. Det eneste, du kan gøre, er at engagere dig bevidst og så kompetent som muligt i de lokale interaktioner og derigennem løbende bearbejde konsekvenserne, som de fremkommer (Stacey \& Mowles, 2016:300). Så vel kan man tage feltherrebeslutninger, men man kan ikke på tilsvarende feltherrevis slå sig igennem til det intenderede udkomme. Det er et udfordrende dilemma, men også et nødvendigt tankesæt for tillidsperspektivet.

\section{Udfordringen om entydig kobling mellem formel og reel drivkraft}

Det officielle rationale for adopteringen af det risikobaserede reguleringsparadigme har jeg klarlagt ovenfor. Nemlig en systematisk risikobaseret prioritering af reguleringsobjekter og effektiv anvendelse af kontrol- og tilsynsressourcer over for aktører, der vurderes mest "risikable". Men hvis der underliggende eller parallelt er andre rationaler og motiver, der står i et paradoksalt forhold til dette officielle rationale, vil det kunne påvirke udkommet, fordi der netop består et indbygget modsætningsforhold. At sådanne underliggende paradokser forekommer i erhvervsvirksomheders udmøntning af ledelseskoncepter som ERM, er blandt andet påvist af (Henriksen \& Møller, 2009, 2010), og det er derfor nærliggende at se efter tilsvarende træk i det offentlige forvaltningsregime. Michael Power har fremført det synspunkt, at det risikobaserede styringsparadigme er modernitetens tendens til at ville håndtere risiko gennem "kontrol af kontrollen" (Power, 1997a), (Power, 1997b). Dermed menes et paradigme, der rationaliserer og bureaukratiserer organisationers dagligdag gennem intensiverede auditerings- og kontrolprocesser, og som en mekanisme til at distribuere og overdrage ansvaret for handlinger og beslutninger til andre (Power, 1997b), (Power, 2004), (Power, 2007), (Power, 2009). Power indikerer således en potentiel tilstedeværelse af indbyggede konflikter mellem de formelle og de reelle drivkræfter og rationaler for anvendelsen af risikobaserede forvaltningsregimer.

Det er således nærliggende at anskue RBRK-paradigmets indtog som et tegn på det offentlige livs adoptering af den risikostyringsdiskurs, der har præget den forretningsorienterede verden siden slutningen af 1990'erne, hvor det har kunnet spille en central rolle i udbredelsen af New Public Management-tanken, hvilket en række forfattere da også gør, f.eks. (Hutter, 2005), (Christopher 
Hood \& Rothstein, 2001), (Rothstein, Huber, \& Gaskell, 2006), (Power, 2007). Introduktionen af paradigmet om risikobaseret regulering er således nært forbundet med ideerne om afbureaukratisering af den offentlige sektor, bedre og mere effektiv regulering, der på den ene side skal overkomme regulators udfordring med at afstemme ressourcerne med opgavens kompleksitet og på den anden side skal reducere tilsynsobjekternes administrative byrder (Hutter, 2005), (Christopher Hood \& Rothstein, 2001), (BLACK \& BALDWIN, 2010). Hood og Rothsteins (ibid.) tillægger, at rationalet også er drevet af et mål om "good governance" i betydningen øget åbenhed og gennemsigtighed, mens (Rothstein et al., 2006) trækker en parallel til Ulrich Becks idé om risikosamfundet, fordi det moderne byder på mange nyopståede risici, der kalder på en organiserende idé, der kan understøtte beslutningstagen. Det behov byder det risikobaserede paradigme som regulatorisk rammeværk ind på, netop fordi risikosamfundet også udfolder sig som et reguleringssamfund. For (Black, 2010) er udgangspunktet at fostre øget risiko-bevidsthed, der kan opnås gennem en systematisk og standardiseret tilgang, der kan medvirke til regelforenkling, men også, at der i paradigmet er en iboende politisk drivkraft, fordi det i sig selv kan bidrage til øget legitimitet til lovgiverne.

Et andet forhold, der har betydning for nærværende diskussion, er de forvaltningsprincipper, som myndighedernes kontrol- og tilsynsaktiviteter bygger på. Vi taler her om paradigmets udmøntning og hvilen på ideen om ledelsessystemer og egenkontrol, der træder i stedet for den direkte myndighedskontrol. Altså en slags "udlejrings-mekanisme", hvis vi skal følge Anthony Giddens terminologi. (Tombs \& Whyte, 2013) har peget på, at der heri er iboende en tydelig kobling til tillidsperspektivet, først og fremmest i den betydning, at reguleringslogikken tilskriver, at kontrolog tilsynsomfanget tilpasses myndighedens tillid til reguleringsobjektet. I bestræbelserne på at skabe en kobling mellem de to dagsordener om effektivisering og tillid, har man således fostret ideen om selv-regulering, hvori vægten lægges på, at tilsynsobjektet baserer sig på etablere et godkendt (af myndigheden), eller endnu bedre, certificeret ledelsessystem (f.eks. ISO 9000 eller ISO 14001), hvorunder objektets efterlevelse af stillede krav dokumenteres gennem auditerbare egenkontrol-programmer.

Michael Power har også beskæftiget sig med den tætte kobling til ideen om ledelsessystemer, hvor kontrolobjektet kontrollerer sig selv på baggrund af et auditeret, valideret og godkendt ledelsessystem, hvori man har fastlagt og dokumenteret kontrolobjektets processer og egenkontrolaktivitet (Power, 2004), (Power, 2007). Brugen af egenkontrol-systemer, hvor myndigheden arbejder på baggrund af en mere eller mindre standardiseret ramme, betyder således i praksis, at myndigheden har rationaliseret sin egen kontrolindsats ved at uddelegere den til kontrolobjektet selv. Myndighedens rolle bliver således ressourcemæssigt reduceret, fordi den centreres om at 1) sikre at ledelsessystemet er dokumenteret og opfylder de standardiserede kriterier, 2) kontrollere, 
at kontrolobjektet måler på de fastlagte målepunkter, og dokumenterer samme, og 3) udstikker krav til eventuelle korrigerende handlinger.

Der er således tale om en strategi, der tager afsæt $\mathrm{i}$ at afstemme begrænsede regulatoriske ressourcer væk fra tilsynsobjekter, der demonstrerer effektive egenkontrol-systemer, og i stedet bruge ressourcerne på de mere tvivlsomme. Med andre ord taler vi altså om at anvende de begrænsede myndighedsressourcer overfor de tilsynsobjekter, der ligger i den nedre ende af tillidsskalaen $^{\text {iv }}$. Det afspejler samtidig en opfattelse af risiko-usikkerheds-distinktionen, der bygger på kalkulerbarhed og forudsigelighed. Dermed aner vi også konturerne af en indbygget modsætning mellem de officielle og reelle motivationer, fordi "compliance" til systemet risikerer at blive mere centralt for aktiviteterne end boniteten af de processer, der er systemets genstand. Pointen er således, at efterlevelse af systemkrav risikerer at være vigtigere end at indsamle og agere på informationer og indsigter, der har betydning for beslutningstagen. Og samtidig nedtoner det per automatik indsatsen over for de objekter, der kan dokumentere compliance til systemtænkningen. Dokumentationen af at tilsynsobjektet efterlever systemiske krav, betyder således per definition en lempeligere kontrolindsats. Risikoen er, at det bliver facade uden kritisk udfordring af de bagvedliggende processer. Meget kan tyde på, at det indeholder et upåagtet politisk dilemma, for at netop den mekanisme kan være kritisk, eksemplificeres formentlig af Finanstilsynets tilgang til det løbende tilsyn med Danske Bank, der har udmøntet sig i hvidvask-skandalen. Det er i hvert fald et spørgsmål, der indgår i Rigsrevisionens undersøgelse af hvidvask-sagen (Rigsrevisionen, 2019).

Et andet eksempel - og desværre meget ulykkeligt - kan formentlig findes i de amerikanske luftfartsmyndigheders udlejring af centrale dele af godkendelsesprocessen for Boeing 737 MAX 9flytypen til Boeing selv (FAA, 2019), der måske har medført en mindre kritisk tilgang til uhensigtsmæssige koblinger mellem avancerede teknologiske systemer (Perrow, 1999). Men MAX 9sagen kan man også se som eksponent for det grundlæggende dilemma, modernitetens kompleksiteter stiller lovgivere og myndigheder overfor. For moderne flyteknologi er så teknisk avanceret, at det i sig selv er en umulig forventning, at kontrol- og tilsynsmyndigheder er i besiddelse af den nødvendige detaljerede tekniske ekspertise. Så på den ene side leverer verdens tilstand et logisk rationale for udlejringen til interne og tredjeparts (assessorer) ekspertsystemer, men på den anden side kan det også lede til et tab af kontrol over den sikkerhed, som myndigheden har til opgave at være garant for. Det er, som jeg også har peget på ovenfor, både et dilemma (der er svært at løse), men samtidig også et paradoks, fordi udlejringen i sig selv øger en kompleksitet, den skal bidrage til at reducere.

Denne udlejringsmekanisme til interne og tredjeparts-ekspertsystemer, jf. ovenfor, kan også ses i forlængelse af Powers pointe om ansvarsoverdragelse. I den sammenhæng ser (Krieger, 2013) det 
risikobaserede paradigme som et middel til at imødegå et pres om ansvarlighed ("accountability") på statslige aktører, et pres som vil medføre, at disse skal forsvare og forklare deres beslutninger og deres præstationer over for andre parter. I den betydning optræder det risikobaserede paradigme altså som en slags responsmekanisme og dokumenterbart værn over for offentlighedens intense granskning ("scrutiny") af regulatorernes beslutninger. Det synes at have konsekvenser, der er i konflikt med det officielle rationale. Dels kan det øge presset for rapportering og dokumentation, der kan gøres til genstand for auditering, hvortil risiko-paradigmet tilbyder en tilsyneladende struktureret platform for at håndtere spørgsmålet om ansvarlighed, eller som Krieger (ibid.) udtrykker det, håndtere "blame-gamet". Dermed bliver der tale om en defensiv foranstaltning, der skal tilbyde troværdighed og legitimitet i kraft af det risiko-baserede paradigmes forudsatte videnskabsbaserede og objektive karakter. Men paradokset er, at paradigmet måske langt fra altid ikke tilbyder denne egenskab.

Det "blame-game"-perspektiv, som Krieger henviser til, er især behandlet af (Christopher Hood, 2002), der kalder udlejrings-mekanismen for en "teflon coat", et udtryk, der henviser til at politiske beslutningstagere foretager et trade-off mellem deres politikvalg og egen risiko for "blame", altså risikoen for at pådrage sig ansvar og skyld vis-a-vis de politiske valg. Med det som drivkraft i valget af reguleringsideologi, vil reguleringens objekt således ophøre med at være det primære. I stedet kan vi se det som en kobling mellem standarder, der sættes af internationale eksperter og overvåges af autonome "styrelser", hvormed man som politiker og lovgiver sætter sig i en position, hvor man kan omfordele og distribuere skyld og ansvar. (Rothstein et al., 2006) har påpeget, at når man skal konstruere regulatoriske objekter i risiko-termer, vil det medføre en defensiv og procedural rationalitet for regulatorerne, hvormed de kan håndtere såvel deres regulatoriske objekter som deres forstærkede institutionelle trusler. Det kan, argumenterer (Rothstein et al., 2006), lede til "risk colonization" som en selvforstærkende proces, hvor risici i stigende omfang kommer til at definere objektet, metoder og selve reguleringens rationale.

Vekselvirkningen mellem "blame" og risiko er formentlig ikke i almindelighed bevidste valg, men det rører som sådan ikke ved det faktum, at relationen mellem det risikobaserede reguleringsparadigmes kobling og afhængighed af ideen om ledelsessystemer og egenkontrol indeholder de elementer, der skal til for at sprede risikoen for "blame", f.eks. gennem øget delegering (ledelsessystem og egenkontrol) frem for klassisk direkte kontrol. Man kan i parentes bemærket synes, at paradokset i det tankesæt er, at det synes fortrængt, at det grundlæggende politiske valg netop var at træffe beslutning om reguleringsstrategien per se, hvori det største ansvar burde ligge. 
Et eksempel på modernitetens "blame"-aspekt, der samtidig trækker stærke tråde til mediers og eksperters italesættelse og fortolkning af risiko-usikkerheds-perspektivet, finder vi i en ny rapport om fejldiagnoser i sundhedssystemet, der for nylig har været meget fremme i medierne (Dansk Selskab for Patientsikkerhed, 2019). Rapporten, og ikke mindst dens mediemæssige eksponering, italesætter eksplicit det, der i retrospekt viser at være forkerte eller ikke fuldt korrekte diagnoser, som fejl. Fejl opfatter de fleste af os som noget negativt, og det inviterer til en søgen efter nogen at gøre ansvarlige. Når man på den måde generaliserer felter, der ofte indeholder betydelige grader af kompleksitet og tvetydighed, der kræver professionelle skøn, som "fejl” og "fejl-diagnoser", afslører man også en opfattelse af lægefaglighed som noget objektivt og forudsigeligt. Deri ligger en opfattelse af enhver patient som et bundt af kendte kausale sammenhænge, der er kalkulerbare og kan sandsynliggøres med høj sikkerhed. En sådan opfattelse er problematisk, fordi den netop skaber en bred opfattelse af, at der til hver en tid er klar og entydig sammenhæng mellem årsag og virkning. Beslutninger, der træffes i usikkerhed, eksisterer i denne opfattelse ikke. Fortid og fremtid bliver uden videre refleksion til samme sag. Men når det så ikke er sådan i virkelighedens verden - har det selvklart negativ betydning for vores tillid til sundhedssystemet. Det er et eksempel blandt mange på, hvordan medier og eksperter ofte, og formentlig ubevidst, bidrager til et skævvride forståelsen af verdens kompleksitet og uforudsigelighed. Resultatet er uheldigt, fordi det medvirker til at forstærke tendensen til at prioritere styringsmekanismer, der indeholder mulighederne for delegering og ansvarsoverdragelse.

Sammenfatning og implikationer: Ovenstående indikerer, at RBRK-paradigmets officielle rationale ikke står alene. Det omgærdes af mange andre motiver, der på forskellig vis kan stå i et direkte paradoksalt forhold til udgangspunktet. Det er selvsagt problematisk, blandt andet fordi det kritiske syn på "sagen" og de indbyggede processer nedtones til fordel for systemets opretholdelse per se. Dertil kommer betydningen af de adfærdsmæssige perspektiver, når udlejringen til ekspertsystemer i praksis styres af en underliggende strøm af omfordeling og delegering af ansvar og skyld. Omvendt, byder modernitetens diskontinuitet på reelle og svært løselige udfordringer, der i hvert fald ikke løses, hvis lovgivere og beslutningstagere negligerer eksistens og betydning af modsætningsfyldte motiver, og dermed ikke handler derpå. Det er et paradoks, der er begrænsende for mulighedsrummet, og som har direkte betydning for tillidsperspektivet, fordi underliggende dagsordener nemt fører til modsatrettede resultater i forhold til det intenderede. Fordi de iboende dilemmaer og paradokser netop er så stærke og udfordrende, er alternativet for beslutningstagerne først og fremmest at få ryddet op i de modsætningsfyldte motiver, og det gør man formentlig bedst ved at identificere indbyggede paradokser og derfra skabe en situation, hvor modsætningerne fjernes eller reduceres. Det kan Chris Mowles (Mowles, 2016) give nogle gode bud på. 


\section{Udfordringen om usikkerhedens kalkulerbarhed}

Jeg har ovenfor fremført den påstand, at risiko-usikkerheds-distinktionen har betydning for det risikobaserede reguleringsparadigmes anvendelsesområde og effektivitet. Den påstand, der i sidste ende relaterer til spørgsmålet om usikkerhedens kontrollerbarhed, kan dog - som jeg antyder ovenfor - muligvis gradbøjes afhængig af, om vi befinder os på det politiske makroniveau eller på det udførende forvaltningsniveau.

For at komme det nærmere, må vi se lidt nærmere på begreberne. Hvis vi laver en skarp afgrænsning eller todeling af risiko-begrebet i Knightske termer (Knight, 1921), dvs. hvor termen "risiko" tilknyttes såkaldt "målbar" usikkerhed, altså noget, der kan sandsynliggøres og kalkuleres, eller anvender termen "usikkerhed", hvor grundlaget for forudsigelse er ukendt, fordi relationen er unik, og der dermed ikke eksisterer et stort homogent empirisk grundlag, har vi etableret et opmærksomhedspunkt, der er kritisk for forvaltningens effektivitet, og antyder dermed en potentiel afgrænsning af, hvor og hvordan vi anvender os af risikobaseret regulering. Omvendt, hvis vi i stedet forstår usikkerhed som en slags funktion af dynamik og kompleksitet (Duncan, 1972), (Giddens, 1990), (Sondhi, 1999), og hvori risiko er et iboende potentielt element af usikkerhed, har vi samtidig også fremhævet to centrale kendetegn ved det moderne samfunds diskontinuitet og centrale faktorer, der relaterer direkte til tillidsdimensionen. Sondringen mellem en risikofortolkning, der bygger på risikoens kalkulerbarhed over for en risiko-usikkerheds-tolkning, der forsøger at forholde sig til verdens kompleksitet og dynamik, vil uvægerligt have implikationer i forhold til det risikobaserede reguleringsregime, fordi den kommer til at berøre en iboende forudsætning om risikostyringens objektivitet.

Denne udfordring tages retfærdigvis også op af de internationale organisationer, der i særdeleshed påvirker den politiske dagsorden på feltet. OECD understreger udfordringen med en henvisning til "the challenges for risk regulation of increasing interconnectedness in a multi-risk world, including: the need to assess the joint effects of simultaneous exposure to multiple risks; the increasingly rapid spread of risks across networks; and the ubiquitous ancillary impacts of risk regulation such as risk-risk tradeoffs." (OECD, 2010, chp. 4). IRGC, der som tidligere nævnt har et tæt samarbejde med OECD på området, har på det seneste også taget handsken op i erkendelse af, at verdens kompleksitet og interaktion ikke længere kan håndteres med klassiske risikostyringsmetoder, der netop er funderet i tilstedeværelsen af kalkulerbarhed og forudsigelighed. IRGC lægger i udspillet "Improving Risk Regulation" (Allio et al., 2015) stor vægt på, at lovgivere blandt andet forholder sig til en kontekst af "multiple, indbyrdes forstærkende og indbyrdes afhængige koblinger", "øget kompleksitet og synlighed" og en besværlig kombination af "højere forventninger" sammen med "mindre tiltro og tillid" til autoriteterne. 
Disse to organisationer, der føder ind til megen international og national regulering, har altså øje for verdens diskontinuitet i deres anbefalinger til politikdannelse om risikobaseret regulering og compliance. Man tager dermed bestik af verdens tilstand og modernitetens natur og forsøger derfra at påvirke lovgivere til at inddrage nye perspektiver i deres trussels- og risikovurderinger, og dermed i beslutningsgrundlaget om reguleringsmæssige indsatser. Spørgsmålet er så, hvor godt dette udmønter sig i praksis, fordi udpegninger af indsatsområder ofte kan følge under indtryk af fremherskende diskurser, der afspejler andre prioriteringer end et trussels- og risikobillede, der er funderet i løbende analyser af globale og nationale tendenser og udviklinger. Men her er det også et krydsfelt af konkurrerende dagsordener. F.eks. har der i en årrække været opfordringer fra flere internationale organisationer om at øge pandemi-beredskabet (se f.eks. the Global Preparedness Monitoring Boardv), men trods dette har mange lande indtil for nylig nærmest valgt det modsatte. Dertil kommer, at risikobaseret regulering på makroniveau ofte er reaktiv af natur, hvilket eksemplificeres af den prioritet pandemi-beredskaber netop nu er genstand for.finanskrisen udgør også et smertefuldt eksempel på det (Kirkpatrick, 2009). Politisk blev der i årene op til krisen løsnet mange regulatoriske bånd for finanssektoren, der lod sig rive med i vækst-euforien og tog enorme risici med uigennemskuelige instrumenter osv. Investorerne og en stor del af omverdenen var benovede, og ingen greb ind, før det var for sent. På den måde er såvel COVID-19 krisen som finanskrisen begge eksempler, hvor man ex ante kunne have ønsket sig en mere proaktiv risikobaseret prioritering og regulering. Til gengæld har regulatorerne i høj grad taget revanche ex post med skærpede krav til kapitalberedskab og en lang række andre begrænsninger. Det samme vil vi opleve i kølvandet på COVID-19.

Men finanskrisen har på mange måder også været udløsende for en ny-orientering i tilgangen til den risikobaserede regulering på internationalt niveau, hvilket formentlig er grunden til, at (Black, 2010) specifikt fremhæver finanssektoren i den ovenfor nævnte 3-deling, selv om den nok bør ses som en del af makro-niveauet. Men som vi også har set efterfølgende, stopper alle disse nye reaktivt udløste regulatoriske begrænsninger af det finansielle system ikke nødvendigvis skabelsen af nye risici og deraf følgende tabsgivende hændelser. Finanstilsynet lykkedes for eksempel ikke med at begrænse hvidvask-skandalen i rette tid, trods mange tidlige advarsler om behovet for det. Udbytteskat-sagen er et tilsvarende eksempel på en sag, hvor der har været mange tegn på uregelmæssigheder undervejs, men hvor der ledelsesmæssigt ikke er blevet skredet ind, før det er løbet helt løbsk. Her er der meget, der tyder på en uheldig kobling til effektiviseringsdagsordenen, der har drænet SKAT for faglige ressourcer og ledelsesmæssigt overblik (Grønnegård Christensen \& Bjerre Mortensen, 2018). Retfærdigvis er der (heldigvis) også felter, hvor lovgiverne forsøger at være relativt tidligt på bolden, f.eks. på det hastigt accelererende felt om cyber-kriminalitet og cyber security. 
Den reaktive natur er problematisk i forhold til det formelle brede sigte i RBRK, fordi det i sig selv indikerer, at reguleringen ofte vil hvile på en opfattelse af risikobegrebet, der følger Knights snævre definition. Når reguleringen bygger på denne risikofortolkning, er der risiko for, at man overser eller nedprioriterer fremkomsten af nye og emergerende risici, der kunne påkalde sig reguleringsbehov, fordi reguleringen ikke følger på baggrund af overordnede og fremadskuende vurderinger og analyser, og dermed indsigter i tendenser i trussels- og risikobilledet. Men det er samtidig de politiske beslutningstageres store dilemma, fordi mange dagsordener kæmper om den politiske prioritering. Hvad der synes rigtigt i dag, vil ikke nødvendigvis være den rigtige beslutning om et år. Der gives ikke sikkerhed for "rigtige" beslutninger, men det understreger behovet for konstant at søge indsigt i emergerende tendenser.

Man kan på tilsvarende vis finde en del eksempler, der følger af andre politikker, der har et samfundsmæssigt udviklingssigte, og som ikke udspringer af den risikobaserede reguleringsdagsorden. Et eksempel er dagsordenen om effektivisering af den offentlige sektor, der er en dagsorden, der ofte ses i kombination med en anden fremherskende diskurs, nemlig digitaliseringsdagsordenen. Her kan man sige, at lovgiveres og regulatorers tro på IT-systemers effektiviserings-kapacitet og kapabilitet til at erstatte menneskelig erfaring og viden ofte udløser ikke intenderede risici, der får betydning for vores tillid til myndighederne. Skattemyndighedernes mange sager fremstår som ulykkelige eksempler på denne kombination. Det gælder for eksempel udbytteskat-sagen, sagen om ejendomsvurderingssystemet og sagen om inddrivelsessystemet (Rigsrevisionen, 2015), (Grønnegård Christensen \& Bjerre Mortensen, 2018). Udfordringerne med Sundhedsplatformen kan formentlig også indskrives i samme problematik, idet det politiske mål om en fælles og effektiv platform for sundhedsfaglig videndeling og dokumentation, i praksis på mange måder har udviklet sig til en platform for skabelse af nye risici i kraft af systemisk uigennemskuelighed, usikre koblinger til andre systemer (f.eks. medicinmodulet) og ikke mindst et tab af behandlingsressourcer til IT-systemet per se (Rigsrevisionen, 2018).

Eksemplerne ovenfor indikerer, at de internationale organisationers anbefalinger om at inddrage modernitetens kompleksitet og dynamik har vanskeligt ved at slå igennem i den nationale politikdannelse og i reguleringsstrategierne. Det kan naturligvis være et tidsspørgsmål, men kan ligeså godt være en indikation på et grundlæggende dilemma mellem intention og virkelighedens prioriteringer. Under alle omstændigheder indeholder det en række udfordringer, der samtidig relaterer til udfordringen om strategisk uforanderlighed, som jeg diskuterede ovenfor.

Men der ligger i ovennævnte eksempler allerede et fingerpeg om, hvordan man i det udførende niveau håndterer og udmønter risiko-usikkerheds-distinktionen. Som blandt andet (Lloyd-Bostock \& Hutter, 2008) har peget på, bygger oversættelsen af politiske risikomålsætninger til anvendelsen 
i kontrol- og tilsynsmyndighedens indsatser på, at man fastlægger et niveau for "acceptable risk" eller "risk tolerance" for de målsætninger, der er opstillet for det givne reguleringsobjekt. Et niveau for "acceptable risk" vil som hovedregel være en kvantitativt (eller semi-kvantitativt) baseret grænse, der implicit indeholder en forestilling om risiko som en definitiv størrelse, og dermed som noget, der entydigt kan fastlægges, kalkuleres og sandsynliggøres. Implicit i denne forståelse er netop, at den risiko, der ligger ud over risiko-tolerancen (residual risk) også kan anskues som noget definitivt, afgrænsningsbart og forudsigeligt. Så man kan sige, at den metodemæssige forestilling indeholder et paradoks, fordi den forudsætter, at det, der i praksis og reelt er uforudsigeligt, på samme tid er forudsigeligt. Dermed hælder den metodemæssige risiko-usikkerheds-distinktion i retning af Knights "målbare" usikkerhed, der som nævnt foran er funderet i et stort, homogent empirisk grundlag. Det risikosyn er fremherskende i den mere praksisnære litteratur om RBRK, hvor blandt andet (Black, 2010), (BLACK \& BALDWIN, 2010) og (Black \& Baldwin, 2012) tager afsæt i den klassiske risikostyrings metodik med risikoidentifikation, risikoanalyse (prioritering) og risikorespons (Henriksen, 2018). I den klassiske metodik er risikoanalysen som regel funderet i kvantitative eller semi-kvantitative overvejelser gennem estimering af sandsynligheden for at en given hændelse indtræffer og estimering af konsekvenserne, hvis hændelsen indtræffer. Produktet af sandsynlighed og konsekvens udgør grundlaget for at prioritere de risici, der skal håndteres (risikorespons). Den tilgang vil vanskeligt kunne håndtere modernitetens diskontinuitet, fordi den relaterer til sammenhænge, hvor der eksisterer gode historiske og statistiske informationer, der giver rimelige sikkerheder for at kalkulere og estimere risici (Henriksen, 2018). Konsekvensen af at bygge på den klassiske risikostyrings metodik er en begrænsning af reguleringens anvendelsesområde til felter, der kan bedømmes relativt objektivt, og som indeholder en relativ høj forudsigelighed. Det betyder således, at det ikke kan anvendes som global mekanisme, og præcis den distinktion kræver opmærksomhed hos lovgiverne.

Det dilemma om risiko-usikkerheds-distinktionen, som lovgivere og regulatorer møder, kan anskueliggøres gennem luftfartsverdenens sondring mellem safety og security. Safety-begrebet relaterer til sikkerhedsbetragtninger om tekniske systemer, f.eks. et flys tekniske luftdygtighed (Airworthiness), mens security-begrebet relaterer til intenderede anslag mod luftfartssikkerheden (terrorisme). I det ene tilfælde (safety) har vi at gøre med relativt sikre kausale sammenhænge mellem årsag og effekt, fordi der i de fleste tilfælde eksisterer et stort empirisk materiale, der for eksempel er bestemmende for fastlæggelsen af terminer for sikkerhedsinspektioner og vedligeholdelsesprogrammer. I det andet tilfælde (security) er sagen en anden, fordi man ikke kan forudsige, hvem, hvordan og hvornår terrorister vil udføre bevidste og intenderede anslag mod den almene sikkerhed. Der er ingen regelmæssighed og logiske sammenhænge, så her må man tage andre metoder i brug. Her er det et spørgsmål om at overvåge, spore tendenser og tolke - men uden sikkerhed for sammenhæng mellem årsag og virkning. 
I mange af disse tilfælde, hvor viden er mangelfuld, vælger lovgivere og myndigheder i stedet at antage et forsigtighedsprincip som responsmekanisme i forhold til den potentielle risiko. Vi taler her om det såkaldte "Precautionary Principle" (se bl.a. (Rogers, 2011)), der i dette tilfælde materialiserer sig i, at vi alle skal screenes i lufthavnenes sikkerhedskontrol, inden vi kommer ind i afgangshallerne, for selv om myndighederne løbende overvåger tendenser og indsamler efterretninger i bestræbelserne på et fremsynet forsvar, kan vi aldrig vide os helt sikre, fordi terrorister agerer refleksivt, og dermed bevidst søger alternative og mere effektive strategier, der kan udløse størst skade. Et skift i reguleringsstrategi på security-feltet fra overvejende forsigtigheds-baseret til risiko-baseret har en anden vigtig implikation. Med forsigtighedsprincippet som strategi formidler lovgivere og regulatorer offentligheden en perception om en risikotolerance på nul. Det forhold, at vi i dag screener alle i sikkerhedskontrollen, bygger netop på en grundlæggende idé om forebyggelse og deraf følgende 100 \% kontrol, og altså zero-risk - selv om vi egentlig godt ved, at det i praksis er umuligt at opnå. En risikobaseret strategi, for eksempel gennem såkaldt profilering af kendte og forhånds-screenede passagerer og kunder, vil derimod introducere en tilbageværende (residual) og ukvantificerbar risiko, fordi risikostyringen så prioriterer indsatsen overfor de personer og processer, som vi forventer, har den største tilbøjelighed til terror. I praksis udmøntes det godt nok omvendt, nemlig ved at friholde eller lempe kontrollen overfor personer, som vi anser for kendte og sikre. Men resultatet af denne profilering er det samme. I EU anvendes profilering i dag på luftfragtsområdet (kendt kunde-princippet), og advokeres også af lovgivere og industri på passagersiden (OECD, 2009).

Sammenfatning og implikationer: Hvis lovgiver implicit antager, at paradigmet trods den indbyggede snævre risiko-usikkerhedsfortolkning der afdækkes ovenfor, kan anvendes som en universel mekanisme, der dækker såvel forudsigelige som uforudsigelige mønstre og emergerende udviklinger, går man fejl af virkeligheden. Den snævre tolkning betyder, at den anvendelsesmæssige udstrækning begrænses til de felter, hvor kalkulerbarheden råder. Det skal lovgiver være bevidst om - og enten være restriktive i valget af reguleringsområder eller udvikle og indtænke nye tankesæt og metoder, der bedre inddrager modernitetens komplekse natur. På det udførende forvaltningsniveau er det på samme måde centralt, at man antager en kritisk tilgang til, hvor og hvordan man udmønter tilsynsstrategierne. Alternativet er, at RBRK fortsætter med anvendes på områder, hvor det ikke gør fyldest. Og det har, som vi har set, negativ betydning for tillidsfastholdelsen.

\section{Afsluttende diskussion og konklusion}

Vores samfundssystem hviler på borgernes tillid til "systemerne". Uden denne systemtillid eroderes samfundskontrakten med uønskede konsekvenser. Men fastholdelse af systemtilliden er udfordret 
af den moderne verdens store dynamik og kompleksitet, der i sig selv udfordrer den politiske og forvaltningsmæssige prioritering, kontrol og styring af samfundsmæssige udviklinger. Jeg har derfor taget afsæt i ideologien om det risikobaserede reguleringsparadigme som ét eksempel på en fremherskende politisk og regulatorisk tænkning, der har en direkte kobling til den helt grundlæggende udfordring med at fastholde tilliden til de samfundsbærende institutioner og systemer. Strategiens rationale er en systematisk og struktureret risikobaseret prioritering af reguleringsobjekter samt ressourceeffektiv anvendelse af kontrol- og tilsynsressourcer over for aktører, der vurderes mest "risikable".

Strategien er, som det fremgår ovenfor, bredt anvendt i Danmark. Men trods dens eksplicitte formål, ser vi mange sager, der på forskellig vis har fået negativ betydning for den systemtillid, som paradigmet har til formål at bidrage positivt til. Det afføder flere spørgsmål til paradigmets rationaler, anvendelse, udmøntning og potentielle begrænsninger. Det synes at være et paradoks, når vi sammenholder med strategiens officielle rationale. For risikobaseret regulering kan ikke på samme tid både være en tillidsbevarende mekanisme og ikke være det. For at komme nærmere på svar, har jeg opstillet og diskuteret 3 grundudfordringer, som paradigmet i yderste konsekvens bør kunne håndtere eller i hvert fald give rimeligt klare svar på. Det er udfordringer, der relaterer til de iboende forudsætninger, som paradigmet bygger på, og som er vigtige i forhold til håndteringen af den moderne verdens diskontinuitet. Vi taler om den indbyggede strategiske tænkning, koblinger mellem motiver og praktik samt spørgsmålet om, hvor vidt den iboende risikotolkning kan levere et relevant modsvar til verdens diskontinuitet.

Analysen af de 3 grundudfordringer afdækker, at paradigmet - som konstrueret og anvendt - ikke bidrager til bearbejdning og håndtering af usikkerhed og uforudsigelighed på strategisk niveau, først og fremmest fordi der blandt beslutningstagere ikke er en grundlæggende erkendelse og håndtering af det forhold, at strategier sjældent fører til det intenderede resultat. Den mangel er problematisk i forhold til tillidsbevarelsen, især fordi der i vores forventninger til det offentlige domæne, er forventning om en rimelig grad af overensstemmelse mellem mål, strategi og udkomme. Eksempelvis, at når vi sætter et politisk mål om en forandringsproces, der skal føre til en top-effektiv og retfærdig skatteforvaltning, men i stedet får kaos og spild af samfundets ressourcer, kan det ikke undgå at give skår i systemtilliden. Den effekt vil sandsynligvis forstærkes jo flere gentagelser. Den begrænsede evne til at bearbejde strategisk uforudsigelighed forstærkes af et andet af analysens bidrag. Nemlig det forhold, at den iboende risiko-usikkerhedstolkning er rodfæstet i en forståelse, der bygger på kalkulerbarhed og sandsynliggørelse, og dermed på en forventning om forudsigelighed. Den fortolkning kan i sagens natur ikke bidrage væsentligt til indblik og forståelse af betydende emergerende tendenser og udviklinger. Dertil kommer, at når paradigmets officielle rationale i praksis nedtones eller bliver overtaget af andre rationaler, risikerer man at tabe de 
potentielt gode effekter på gulvet. Når de bagvedliggende uofficielle drivkræfter styres af mål om afbureaukratisering og effektivisering, vil det officielle rationale ophøre med at være det primære. Og når det så sammenkobles med, at udlejringen til ekspertsystemer i praksis styres af en underliggende strøm af omfordeling og delegering af ansvar og skyld, får vi den konsekvens, at det processuelle syn afløses af hensynet til systemets opretholdelse i sig selv, altså den såkaldte systemcompliance.

Analysen afdækker således en grundlæggende konflikt mellem 2 modsætningsfyldte verdensanskuelser. På den ene side en anskuelse, hvor verden kan fortolkes som bestående af identificerbare lineære koblinger og på den anden side en anskuelse, der ser verden som fyldt med uforudsigelighed. I den lineære verden tilbyder RBRK instrumentel kausalitet. Når vi gør A, får vi også det forudsatte B. Det gør tingene enkle og giver en følelse af håndterbarhed og kan, som Nils Brunsson har vist, fastholde vores drøm om rationalitet (Brunsson, 2006). Men analysen afslører også, at som universelt instrument er den anvendelse farefyldt for den tillidsbærende kapabilitet, netop fordi den kun iagttager et udsnit af verdensbilledet. Den non-lineære verden derimod er besværlig, uhåndterbar og uforudsigelig, og kan ikke uden videre håndteres instrumentelt.

Min overordnede konklusion er derfor, at der ikke findes nogle globale metodikker, der kan hjælpe os til at besvare alle de spørgsmål, som verdens diskontinuitet stiller os. Det gælder også for det risikobaserede regulerings- og kontrolparadigme, der som strategisk instrument og forvaltningsparadigme ikke på meningsfuld vis kan bidrage til at bygge bro over de paradokser, der er afdækket. Dertil er det alt for rodfæstet i en kontekst af instrumental kausalitet. Som forvaltningsparadigme er dets anvendelsesområde begrænset til de domæner, hvor kalkulerbarhed og sandsynliggørelse er normen. Dvs. domæner, hvor der eksisterer solide historiske datagrundlag, der med en rimelig grad af kausalitet kan kobles til forventede udkommer. Hvor usikkerhed og uforudsigelighed råder, må andre tankesæt tages i brug. Det er efter min opfattelse en vigtig, men samtidig udfordrende konklusion, for vi kan ikke fortsætte uændret, hvis relationen til systemtilliden skal varetages bedst muligt. Hvis jeg har ret i konklusionen om et anvendelsesfelt, der er langt mere snævert end den faktiske anvendelse, er det nærliggende at spørge, hvorfor paradigmet direkte som indirekte er kommet til at spille så stor en rolle i nutidens politikdannelse og offentlige forvaltning. Det kan i sig selv synes helt irrationelt (paradoksalt nok), ikke mindst fordi det i sidste ende har betydning for vedligeholdelsen af systemtilliden. Hvorfor dog bruge samfundets ressourcer på politikker, der ikke helt virker? Jeg ser to grundlæggende svar.

For det første, at paradokset er en følge af grundlæggende samfundsmæssige tendenser, der har bevæget sig de seneste mange år, og som manifesterer sig i dagsordener om afbureaukratisering og effektivisering af den offentlige sektor. Vi taler her om den offentlige sektors adoption af det private 
erhvervslivs styringsprincipper. Her den klassiske risikostyrings principper. Alt skal kunne måles og vejes for at skabe et grundlag for kausale koblinger og forudsigelighed. Denne vinkel taler sig lige ind i Brunssons påpegning af den rationelle drøm, som vi vil gøre alt for at fastholde. For det andet er det nærliggende at antage, at meget få beslutningstagere, eller måske nærmere ingen, gør sig betydningen af distinktionen mellem det forudsigelige og uforudsigelige klart. Dermed står paradigmets anvendelsesmæssige begrænsninger heller ikke klart. Med den konsekvens, at der fortsættes på et rationale om forudsigelighed og linearitet. Altså et rationale, der overser eksistensen af dynamik og kompleksitet.

Det er problematisk, fordi det har påvirkning på tillidsbevarelsen, og det efterlader os med en klar udfordring, som formentlig kun kan håndteres meningsfuldt, hvis der skabes beslutningsmæssig bevidsthed om sondringen, og derfra antages en klar forvaltningsmæssig grænsesætning mellem den lineære og den non-lineære verden. Derfor er det afgørende for tillidsdimensionen, at RBRKparadigmet i sin anvendelse begrænses til de felter, hvor forudsigelighed og linearitet er hovedreglen. Dvs. felter hvor risici kan sandsynliggøres og kalkuleres med en rimelig grad af forudsigelighed, og hvor de klassiske risikostyringsmetoder kan anvendes. Det betyder samtidig, at RBRK-paradigmets anvendelsesområde bør begrænses til det operationelle domæne, jf. (Black, 2010)'s opdeling.

Den opsplitning, jeg her foreslår, udløser andre spørgsmål. Først og fremmest er det afgørende, at der er politisk og forvaltningsmæssig bevidsthed om, at det risikobaserede regulerings- og kontrolparadigme ikke kan give universelle svar. Der er i særdeleshed behov for opmærksomhed på de bagvedliggende samfundsmæssige tendenser, der hele tiden udløser en søgen efter entydige svar på komplekse udfordringer. Det er i langt de fleste tilfælde en utopi. Man kan i den udlægning anskue paradigmet som et symptom på en uheldig udvikling, hvor ingen rigtig ønsker at tage ansvar. I stedet bliver det en verden styret af system-compliance, hvorigennem vi skaber dokumentation med det underliggende, men primære formål at producere bevis for at have gjort det forventede. Men det tankesæt har den ulempe, at sund fornuft, faglig indsigt og ekspertise nedgraderes. Det har begrænset værdi i ansvarsfraskrivelsens tidsalder, og dermed taber vi på en række felter selve grundtanken i RBRK-paradigmet på gulvet, altså ideen om udnytte kompetencer og ressourcer effektivt. I stedet udløses en strøm af uintenderede effekter, der påvirker vores systemtillid negativt. Det tab kunne vi formentlig begrænse, hvis vi antog en langt mere kritisk tilgang til indbyggede dilemmaer og paradokser i strategier og metoder.

Sondringen mellem de to verdensbilleder efterlader os, som antydet ovenfor, med en uløst udfordring om hvordan vi bedre kan håndtere den dilemma- og paradoksfyldte del af virkeligheden. Hvis vi igen tager Blacks (Black, 2010) foran nævnte opdeling i et makro-perspektiv og et operationelt 
perspektiv som udgangspunkt - kan man til det første sige, at statens afgrænsning og fastlæggelse af mål / grænser for en række identificerede og emergerende samfundsmæssige risici, som for eksempel forhold, der knytter sig til kritisk infrastruktur, sundhed, miljø, sikkerhed osv. absolut giver mening, fordi det kan hjælpe med at udforme helt overordnede krav til politikker og til centrale virkemidler.

Men det er nemmere sagt end gjort, for her bevæger vi os ind i et domæne af usikkerhed og uforudsigelighed. Vi taler om multiple fremtider, der ikke kan fastlægges og defineres på forkant. Udfaldsrummet er stort og bredt. Vi kan med kontinuerlig overvågning, scenarie-udvikling, dataindsamling og kritisk sans godt optegne mulige fremtider og på den baggrund etablere et grundlag for beslutningstagen og prioritering. Derved vil vi som regel kunne indsnævre udfaldsrummet i en eller anden grad. Men graden kan vi selv sagt ikke forudsige. Sikre bliver vi aldrig, fordi det eneste forudsigelige er, at fremtiden er uforudsigelig. Den sammenhæng er vi nødt til at acceptere, hvis vi skal blive bedre til at lære af mulige indsigter.

Det betyder implicit, at vi uvægerligt vil tage fejl fra tid til anden. Den største udfordring er, at dette faktum ikke rigtig erkendes i modernitetens hurtiggående samfundsliv. Hurtige og sikre orakel-svar forventes overalt, hvorimod den iboende usikkerhed, der knytter sig til skøn og vurderinger, er blevet til begreber, der kun sjældent anerkendes. Faglighed og ekspertviden er blevet til politiske domæner, hvor det er umuligt at afgøre, hvor fagligheden ophører og politikken begynder. Det har den konsekvens, at det slører beslutningsgrundlag, og dermed forstærker tendensen til "systemcompliance" og "blame-game". Vi bærer alle sammen et medansvar for den udvikling, fordi vi alle er deltagere i krydsfeltet af samfundsmæssige udviklinger. Men især medier og politikere, der har en særlig rolle i magtdelingen, burde have en særlig forpligtelse til at værne om samfundskontrakten. Men i stedet er de på mange måder snarere stærkt medvirkende til at forstærke tendensen. Forløbet under COVID19-krisen er et godt eksempel på disse træk. Det er det netop, fordi den initiale konsensus om at tage forsigtighedsprincippet i anvendelse som følge af den rådende enorme usikkerhed, undervejs forandrer karakter til problematisering i takt med øget viden og overblik. Hurtigt glemmes det, at forsigtighedsprincippet havde rodfæste i den initiale usikkerhed. I stedet sættes der lighedstegn mellem ny og gammel viden. Det har den konsekvens, at rationalet bag forsigtighedsprincippet fordamper og udviskes. Dermed kan en beslutning truffet i usikkerhed vendes til en fejl.

Det er ikke en udvikling, der fører til bedre beslutninger. Tværtimod vil den føre til endnu flere beslutninger truffet i ly af "system-compliance", der på ingen måde tager hånd om de reelle udfordringer. Derfor er en grundlæggende italesættelse og samfundsmæssig debat om disse udviklinger helt nødvendig. 
Hvis vi afslutningsvis for et øjeblik vender tilbage til de dilemmaer og paradokser, der er anført undervejs, og som jeg også indirekte trækker på ovenfor, er der 2 ting, der kan uddrages. For det første, knytter dilemmaer og paradokser sig ret konsekvent til det at træffe beslutninger i usikkerhed. I nærværende sammenhæng påhviler det ansvar først og fremmest samfundslederskabet, men det er, som Stacey og Mowles har vist, til gengæld sjældent eller nærmest aldrig lederne, der ene og alene er afgørende for udfaldet. Men det er lederne, der har en særlig forpligtelse til at gøre det mulige for at påvirke udfaldet, og præcis det bliver de nødt til at forholde sig til, når målet er at bevare systemtillid, og i sidste ende, samfundskontrakten.

For det andet, er erkendelsen af de dilemmaer og paradokser, der udfolder sig, vigtige, for det er en mega-opgave lovgiver og regulator står over for i forhold til modernitetens diskontinuitet. Der findes ingen lette og simple løsninger på det. For lovgivere, medier og eksperter drejer det sig om realisme og ærlighed. Realisme om, hvad der kan lade sig gøre, og ærlighed om, at der ikke eksisterer rationelle kausale koblinger på alt. Og dermed heller ikke quick-fixes. Er det utopi? Nogen vil sikkert mene, at det er tvivlsomt, om det grundlæggende står til at ændre, fordi den instrumentelle dagsorden er en så stærk diskurs drevet af rationalister med stor indflydelse. Omvendt bør de indbyggede dilemmaer og paradokser besidde en vis styrke til at begrunde behovet for italesættelse og samfundsmæssig debat om den rationelle instrumentalitets begrænsninger. Så er vi på vej. 


\section{Referencer}

Allio, L., Scott, C., Yosie, T., Renn, O., Florin, M.-V., Oye, K. A., ... Hoos, A. (2015). Improving Risk Regulation. https://doi.org/10.5075/epfl-irgc-228198

Beck, U. (1992). Risk Society: Towards a New Modernity. london: Sage Publications.

Black, J. (2012). Paradoxes and Failures: "New Governance” Techniques and the Financial Crisis. The Modern Law Review, 75(6), 1037-1063. Retrieved from https://doi.org/10.1111/j.1468$\underline{2230.2012 .00936 . x}$

Black, J., \& Baldwin, R. (2012). When risk-based regulation aims low: Approaches and challenges. Regulation \& Governance, 6(1), 2-22. Retrieved from https://doi.org/10.1111/j.17485991.2011.01124.x

BLACK, J., \& BALDWIN, R. (2010). Really Responsive Risk-Based Regulation. Law \& Policy, 32(2), 181-213. Retrieved from https://doi.org/10.1111/j.1467-9930.2010.00318.x Brunsson, N. (2006). Mechanisms of hope: Maintaining the dream of the rational organization. Copenhagen: Copenhagen Business School Press. https://doi.org/10.1177/13505084070827551

Christiansen, U., Kjærgaard, A., \& Hartmann, R. K. (2012). Working in the shadows: Understanding ERP usage as complex responsive processes of conversations in the daily practices of a Special Operations Force. Scandinavian Journal of Management, 28(2), 173-184.

https://doi.org/10.1016/j.scaman.2012.01.002

COSO. (2004). Enterprise Risk Management - Integrated Framework. The Committee of Sponsoring Organizations of the Treadway Commission (Published through AICPA, Jersey City, USA).

COSO. (2016). Enterprise Risk Management - Aligning Risk with Strategy and Performance. Retrieved from https://www.coso.org/Documents/2017-COSO-ERM-Integrating-with-Strategy-andPerformance-Executive-Summary.pdf https://doi.org/10.1002/9781118269145.ch8

Duncan, R. B. (1972). Characteristics of Organizational Environments and Perceived Environmental Uncertainty. Administrative Science Quarterly, 17(3), 313-327. https://doi.org/10.2307/2392145

Frederiksen, M. (2014). Trust in the face of uncertainty: a qualitative study of intersubjective trust and risk. International Review of Sociology, 24(1), 130-144. Retrieved from https://doi.org/10.1080/03906701.2014.894335

Frederiksen, M. (2019). Usikker modernitet: Danske voerdier fra 1981 til 2017. Kbh.

Giddens, A. (1990). Modernitetens konsekvenser. København: Hans Reitzels Forlag. https://doi.org/10.7146/politica.v27i2.67933

Grønnegård Christensen, J., \& Bjerre Mortensen, P. (2018). Overmod og afmagt: Historien om Det 
nye SKAT (J. Ø. F. DJØF, Ed.). København: Jurist- og Økonomforbundets Forlag. DJØF. https://doi.org/10.7146/politica.v22i3.69232

Hardin, R. (2002). Trust and trustworthiness. New York.

Henriksen, P. (2018). Enterprise Risk Management. rationaler og paradokser i en moderne ledelsesteknologi. CBS.

Henriksen, P., \& Møller, R. Y. (2009). Den moderne risikostyrings drivkræfter og motiver. Et teoretisk pespektiv. Økonomistyring \& Informatik, 25(6), 477-498.

Henriksen, P., \& Møller, R. Y. (2010). Den moderne risikostyrings drivkræfter og motiver (2. del). Et empirisk perspektiv. Økonomistyring \& Informatik, 26(1), 15-47.

Hood, C, Rothstein, H., \& Baldwin, R. (2001). The Government of Risk: Understanding Risk Regulation Regimes. Oxford: Oxford University Press. https://doi.org/10.1111/j.14777053.2004.00133.x

Hood, Christopher. (2002). The Risk Game and the Blame Game. Government \& Opposition, 37(1), 15-37. Retrieved from https://doi.org/10.1111/1477-7053.00085

Hood, Christopher, \& Rothstein, H. (2001). Risk regulation under pressure: Problem solving or blame shifting? Administration and Society, 33(1), 21-53.

https://doi.org/10.1177/00953990122019677

Hutter, B. (2005). The attractions of of risk-based regulation:accounting for the emergence of risk ideas in regulation. CARR Discussion Paper (Vol. 33). Centre for Analysis of Risk and Regulation, London School of Economics and Political Science

ISO. (2009). ISO 31000:2009 (First edition). Retrieved from www.iso.org

Kirkpatrick, G. (2009). Corporate Governance Lessons from the Financial Crisis. OECD Journal: Financial Market Trends, 2009(1), 61-87. https://doi.org/10.1787/fmt-v2009-art3-en

Krieger, K. (2013). The limits and variety of risk-based governance: The case of flood management in Germany and England. Regulation \& Governance, 7(2), 236-257. Retrieved from https://doi.org/10.1111/rego.12009

Lloyd-Bostock, S. M., \& Hutter, B. M. (2008). Reforming regulation of the medical profession: The risks of risk-based approaches. Health, Risk \& Society, 10(1), 69-83. Retrieved from https://doi.org/10.1080/13698570701782460

Luhmann, N. (1999). Tillid - en mekanisme til reduktion af social kompleksitet. København: Hans Reitzels Forlag. https://doi.org/10.7146/tfp.v12i22.96793 
Mowles, C. (2016). Ledelse i usikkerhed. Arbejdslivets daglige kompleksitet og paradokser. (1. udgave). Danmark: Dansk Psykologisk Forlag.

Murtini, F., Fleischeri, L., Siegerinki, V., Aassveii, A., Alganiii, Y., Boarinii, R., ... Smithi, C. (2018). Trust and its determinants: Evidence from the Trustlab experiment. Retrieved from https://doi.org/10.1787/869ef2ec-en.

OECD. (2010). Risk and Regulatory Policy. https://doi.org/10.1787/9789264082939-en Perrow, C. (1999). Normal Accidents - Living With High Risk Technologies. New Jersey: Princeton University Press.

Power, M. (1997a). From Risk Society to Audit Society. Soziale Systeme, (3), 3-21.

Power, M. (1997b). The Audit Society. Oxford: Oxford University Press.

Power, M. (2004). The risk management of everything. Rethinking the politics of uncertainty. Retrieved from https://www.demos.co.uk/files/riskmanagementofever

Power, M. (2007). Organized Uncertainty. Oxford: Oxford University Press.

Power, M. (2009). The risk management of nothing. Accounting, Organizations \& Society, 34(6/7), 849-855. https://doi.org/10.1016/j.aos.2009.06.001

Rogers, M. D. (2011). Risk management and the record of the precautionary principle in EU case law. COURT of Justice of the European Communities, 14(4), 467-484.

https://doi.org/10.1080/13669877.2010.547255

Rothstein, H., Huber, M., \& Gaskell, G. (2006). A theory of risk colonization: The spiralling regulatory logics of societal and institutional risk. Economy \& Society, 35(1), 91-112.

https://doi.org/10.1080/03085140500465865

Solsø, K., \& Thorup, P. (2015). Ledelse i kompleksitet. En introduktion til Ralph Staceys teori om organisation og ledelse (1. udgave). Dansk Psykologisk Forlag.

Sondhi, R. K. (1999). Total Strategy (First). Bury, Lancashire: Airworthy Publications International Ltd.

Stacey, R. D. (2012). Tools and techniques of leadership and management: Meeting the challenge of complexity. London: Routledge.

Stacey, R. D., \& Mowles, C. (2016). Strategic Management and Organisational Dynamics (7th ed.). Pearson Education Limited, Harlow, UK.

Uslaner, E. M. (2013). Trust as an alternative to risk. Public Choice, 157(3/4), 629-639. Retrieved 
from http://www.jstor.org.esc-web.lib.cbs.dk/stable/24507630

\footnotetext{
${ }^{i}$ Skatteminister Morten Bødskov er også bevidst om, at Skattemyndighedernes mange problemer har betydning for befolkningens tillid, se kronik i Politiken 13. sep 2019, 2. sektion, p. 7-8 ("sådan får vi tilliden til skattesystemet tilbage"). Bødskov peger på 3 ting - flere kompetente menneskelige ressourcer, mere realisme i troen på IT-systemers effekt og mere ro og stabilitet (konsolidering) organisatorisk. På den måde udfordrer han faktisk nogle grundpiller i New Public Management - ret interessant. Måske er der ved at indfinde sig en vis refleksion over de hidtil oversete paradokser.

ii Om danskernes tillid: https://www.dr.dk/nyheder/politik/folketingsvalg/taet-paa-hver-anden-danskerstoler-ikke-paa-folketinget Tilliden til erhvervslivet også er vigtigt. Ny analyse fra FSR nævnt af Leif Beck Fallesen i Politiken 15/9 2019 https://www.fsr.dk/Nyheder\%200g\%20presse/Nyheder/2019nyheder/Tilliden\%20til\%20erhvervslivet\%20daler

iii Den danske betegnelse "komplekse interaktioner" for Complex Responsive Processes skal tilskrives (Solsø \& Thorup, 2015).

${ }^{\text {iv }}$ Dette forhold forklarer grunden til, at betegnelsen tillidsbaseret regulering ofte anvendes synonymt med risikobaseret regulering.

v The Global Preparedness Monitoring Board: https://apps.who.int/gpmb/annual_report.html
} 